\title{
The Role of Knowledge Management in Balancing Exploration and Exploitation in E-Commerce Firms
}

\author{
Matthew Andrews \\ International School of Management
}

\author{
Stanley J. Smits \\ Georgia State University
}

This article focuses on the role of knowledge management and organizational learning in e-commerce firms as they develop and prosper; theoretical and applied issues of balancing exploration and exploitation for their survival, growth, and profitability are discussed. Knowledge management is presented as central to learning that facilitates long-term success. The concept of micro-formalization related to Agile management practices is proposed as an approach that allows young companies in dynamic sectors to implement learning systems with an adequate but minimal level of formalization without experiencing crises inherent to traditional life-cycle models, and without resorting to rigid procedures which stifle creativity.

Keywords: start-up firms, e-commerce, exploitation, exploration, organizational ambidexterity, knowledge management, organizational learning, organizational development, organizational life cycles, dynamic capabilities, learning organization, tacit learning

\section{INTRODUCTION}

In order for startup firms to become financially sustainable and survive long-term they must develop, maintain, and distinguish themselves via superior performance. For most firms that means finding ways to sustain the innovation needed to cope strategically with the environmental turbulence germane to Porter's (2008) competitive forces. Various concepts and models in management literature have attempted to describe how this development transpires and what its salient features are. For example, the concept of organizational life cycles developed by Greiner (1972), Quinn and Cameron (1983), and Daft (2010) suggests that enterprises follow similar stages of development as they evolve from the startup stage to later stages involving greater formalization partly in response to the their environments. The concept of dynamic capabilities refers to the ability of an organization and its management to build and to integrate competencies, both internal and external, and to reconfigure those competencies as necessary to adapt to dynamic, rapidly changing contexts (Eisenhardt \& Martin, 2000; Teece, 2007, 2014; Teece et al., 1997). Closely related to dynamic capabilities is the concept of organizational ambidexterity (March, 1991, 1996, 2006; Gupta et al., 2006; O'Reilly \& Tushman, 2004, 2013), which, according to O'Reilly and Tushman allows firms to "both explore and exploit-to compete in mature technologies and markets where efficiency, control, and incremental improvement are prized and also to compete in new technologies and markets where flexibility, autonomy, and experimentation are needed" (2013, p. 324). 
The challenges involved in moving from start-up to long-term viability are common to all organizations but may be somewhat different in e-commerce firms due to the nature of their market environments and typical modus operandi. In earlier papers, we have addressed knowledge management issues facing a young French e-commerce firm. The two major challenges addressed in those papers are summarized in Parts I and II of Figure 1.

\title{
FIGURE 1 \\ LIFE CYCLE CHALLENGES: EXAMPLE OF A FRENCH E-COMMERCE COMPANY
}

\begin{abstract}
I. Start-up and Early Development
Major Challenge: Learning from experience while dealing with the ambiguity and turbulence normal to startup organizations:

- Evolving a shared understanding of the factors critical to organizational success; their causation and underlying knowledge requirements, and

- Using this shared understanding to continuously improve organizational functioning.

Helpful Theory and Research:

- Causal Mapping: A tool to operationalize the tacit knowledge gleaned from shared experience (Ambrosini \& Bowman, 2001)

- Knowledge-in-Practice: Translating the tacit knowledge gained from shared experience into practice improvements (McIver, et al., 2013)
\end{abstract}

Application Examples: Andrews, 2017; Argot \& Miron-Spektor, 2009

\section{Evolving and Sustaining Superior Performance}

Major Challenge: Leveraging learning throughout the organization to develop superior performance:

- Building a fully-functioning learning organization:

[? Capturing and sharing experienced-based learning throughout the organization, and

? Managing the process of leveraging tacit knowledge for superior performance.

Helpful Theory and Research:

- Is yours a learning organization? : A useful diagnostic tool to evaluate and improve the learning capabilities of one's organization (Garvin, et al., 2008)

- Work-relevant knowledge creation: Integrating tacit knowledge methodologies for improved knowledge management (Andrews, 2018)

- Knowledge management: Institutionalizing knowledge for superior performance using the 4I framework: Intuiting, Interpreting, Integrating, Institutionalizing (Crossan, et al, 1999; Lawrence, et al., 2005)

Application Examples: Andrews \& Smits, 2018; Spender, 1993; Yamklin \& Igel, 2012

\section{Ensuring Long-term Viability}

Major Challenge: Balancing exploration and exploitation for long-term survival:

- Evolving a structure and management system that promotes innovation and profitability for the long-term 
In the present paper, we focus Part III in Figure 1, the long-term viability of this e-commerce firm, and then attempt to generalize implications for managing similar firms in dynamic market environments. The first objective of this article is to explore the interrelatedness among these different concepts and models. Organizational learning and knowledge management, for example, undergird a firm's ability to adapt to changing contexts, to successfully evolve from one stage of development to another, and to effectively leverage and deploy competencies. Levels and types of formalization impact routines, learning and knowledge management processes, as well as the firm's ability to assess its environment and to deploy competencies accordingly. The idea here is not to seek a simple scheme whereby one is a prerequisite to the other but rather to shed light on complex ways in which they facilitate one another, overlap, describe similar phenomena and/or diverge.

The second objective of this article is to assess existing concepts and models in light of recent developments, particularly the emergence of e-commerce, which increasingly impacts nearly every aspect of business. Since the early 2000's, new ways of buying and selling online, and using mobile devices have proliferated; this has had a significant disruptive impact on every part of the global value chain, and has challenged existing business models (Laudon \& Traver, 2017). The extent to which theories of organizational life cycles adequately apply to this new era and particularly to enterprises operating in the e-commerce sector is discussed.

The third objective of this article is to review recent advances in the field of knowledge management and to discuss the implications of this progress for understanding how e-commerce companies evolve and achieve superior performance. While the global marketplace has been changing dramatically due to opportunities made possible by advances in information technology and the Internet, there have also been two decades of progress in the emerging discipline of knowledge management; its applications are becoming more central to organizational functioning (Andrews \& Smits, 2018).

This article concludes with a definition of micro-formalization which refers to the use of small organizational units or groups to accomplish specific tasks and projects of relatively short duration and which favor informal hierarchical arrangements; it also refers to the use of informal structures such as communities of practice to encourage the development of a social context where learning takes place. Agile management practices, which provide many examples of micro-formalization are discussed; we propose such practices can help young companies achieve the needed learning and knowledge management systems, and a minimum level of formalization without experiencing development crises inherent to traditional life cycle models, and without resorting to rigid institutional procedures that stifle creativity. Moreover, such practices can help more mature companies maintain innovative learning cycles and thus achieve an optimal balance of exploration and exploitation. The influence of knowledge management, particularly Nonaka's (1994) model of new product development, and his theories on the development of new knowledge has exerted a significant influence on the development of Agile management practices; such a discussion is therefore an appropriate way to address both questions of organizational design and organizational learning.

\section{THE CENTRALITY OF LEARNING IN ORGANIZATIONAL DEVELOPMENT}

\section{Organizational Life Cycles}

Since the 1960's the concept of organizational life cycles has gained traction in scholarly literature (Cawsey \& Deszca, 2007; Daft, 2010; Flamholtz \& Randle, 2006; Greiner, 1972, Quinn \& Cameron, 1983). According to one of the earliest versions of the theory (Greiner, 1972), enterprises evolve through developmental phases that depend on the following key dimensions: the organization's age, the organization's size, periods of stable growth, periods of turbulence, and the industry's growth rate. As the organization grows, management practices that functioned in one phase become less effective; this triggers a leadership crisis which marks a period of transition into the next phase. Quinn and Cameron (1983) later synthesized a number of life cycle models, including Greiner's, and they contributed to the existing models by suggesting that the power of constituencies played an important role because they impose different (i.e. new) criteria for effectiveness on the organization. For example, a company shifting from the startup phase 
to a later phase of development may find that control has shifted from the founder and a narrow group of trusted people to investors and/or to state actors who have a very different vision for running the firm.

More recently, Daft (2010) integrated aspects of Quinn and Cameron's model with Greiner's earlier theory and proposed the following four stages: entrepreneurial, collectivity, formalization, and elaboration. The entrepreneurial stage is defined by creativity, limited formality or coordination, and by the close involvement of the founder(s). The collectivity stage is then marked by a strong sense of commitment to a mission among staff - while some aspects of formalization appear, communication and control remain largely informal. In the formalization stage, to achieve efficiency and control, there is much greater emphasis on rules and structure and this stage is thus characterized by institutional procedures and conservatism. Finally, in the face of a changing business environment, the elaboration stage occurs when the enterprise must adapt by elaborating structures in the form of cross-functional teams, diversification, and/or the creation of multiple divisions

While there is some empirical evidence to support the link between organizational development frameworks and firm performance (Flamholz \& Randle, 2006), on the whole, theories of organizational life cycles are highly conceptual, difficult to apply to specific circumstances, and their validity is hard to measure (Jirasek \& Bilek, 2018). Moreover, in a highly dynamic sector such as e-commerce, the theories appear overly simplistic and deterministic. It seems far from clear that companies necessarily traverse leadership crises to evolve effectively from one stage to the next. Also, while some degree of formalization must undoubtedly develop as companies grow in order to coordinate a wider scope and greater volume of activity, in sectors where innovation is key to survival, we question the assumption implicit in Daft's 2010 model that this formalization inevitably emphasizes rules, procedures, and conservatism. Finally, we question whether companies must reach a level of maturity associated with Daft's elaboration stage in order to develop structures to face a changing business environment.

These questions and criticisms notwithstanding, theories of organizational life cycles have practical value for this discussion and for managers. They provide a template for leadership priorities according to different circumstances and problems; moreover, links can be drawn between stages of development and the extent to which a firm develops explicit and systematic organizational learning processes and practices (Smits \& Bowden, 2015). For example, innovation and learning are likely to be high in the early stages of development when the entrepreneur/leader must communicate the startup innovation to the small group of members recruited to implement it, and communicates the strategy to do so; such learning is likely to be largely informal and involve a substantial degree of improvisation (Barrett, 1998; Fisher \& Barrett, 2019). As the enterprise grows, recently acquired members of the organization learn from the experiences involved in implementing the innovation and penetrating its market niche; given the collegiality and commitment among members that develops, members exchange this experience-based tacit knowledge with each other (Andrews \& Smits, 2018). However, for the tacit knowledge to be institutionalized for competitive advantage, that is, moved from tacit to explicit and mandated for use, systems must be developed and implemented (Crossan, et al., 1999; Lawrence, et al., 2005; Nonaka 1994; Turner \& Makhija, 2006).

\section{Organizational Ambidexterity}

The foundations of the concept of organizational ambidexterity stem from the notion that firms which operate in stable environments tend to develop management systems based on clear hierarchies and job descriptions as well as on clearly defined roles and responsibilities, whereas firms operating in more turbulent environments tend to develop systems less reliant on formalization and specialization, and tend to favor lateral coordination (O'Reilly \& Tushman, 2013, citing Burns \& Stalker, 1961). O'Reilly \& Tushman (2013) contend that "researchers now largely accept that different structural alignments are associated with different strategies and environments" (p. 324). Building on this finding, organizational ambidexterity refers to an organization's ability to adapt both management approaches in order to explore new markets and opportunities through innovation, creativity, and experimentation; as well as to exploit existing markets by increasing efficiency through control and incremental improvements (Gupta el, 2006; March, 1991, 1996, 2006; O'Reilly \& Tushman, 2004, 2013). Ambidexterity may be achieved within an organization sequentially, when the firm shifts structures and resources over time; simultaneously; or 
contextually, when individuals within the firm have discretion to decide how to allot time and resources (O’Reilly \& Tushman, 2013).

Organizational ambidexterity is closely related to the concept of dynamic capabilities defined as "the firm's ability to integrate, build and reconfigure internal and external competencies to address rapidly changing environments" (Teece et al, 1997, p. 516). Eisenhardt and Martin (2000) argued that learning undergirds and guides the development and evolution of the dynamic capabilities. Gupta et al. (2006) furthermore asserted that learning is key for both exploitation and exploration: "Both exploration and exploitation involve learning, albeit of different degrees and types" (p. 703); furthermore, March (1991) in a seminal paper, framed the discussion of exploring "new possibilities" versus exploiting "old certainties" in the context of organizational learning (p. 71).

Simultaneous ambidexterity often requires separating management systems structurally within the company so that different processes, cultures, and structures can develop without conflicting with one another, while the senior executive level maintains links across the different units (O'Reilly \& Tushman, 2004). The dilemma many organizations face is that if they focus too much on exploitation, they will fall into a "success trap" when organizational inertia impedes effective adaptation to changing contexts; whereas if they focus too much on exploration they fall into a "failure trap" when successive innovations use up company resources before they can generate revenue (Junni et al., 2013, p 300). Junni et al. (2013) assert that an optimal balance is therefore crucial to ensuring short- and long-term success. Ambidexterity is particularly important for services and high technology firms because superior performance is difficult to achieve and maintain over time in dynamic environments.

\section{Advances in Knowledge Management and Organizational Learning}

Much has been written about the origins of knowledge management as a discipline, and the various definitions which can be found in the literature (Agrawal \& Mukti, 2020). Hansen and Birkinshaw (2007) describe knowledge management as an attempt to extract value from innovation and learning; and Raelin (1997) states that its focus is on practical applications to improve performance. Knowledge management "emphasizes the concrete, situation-specific value of knowledge rather than theoretical, abstract knowledge" (Andrews, 2018, citing Prusak, 2001). McIver and associates (2013) moreover describe knowledge management as an essential organizational competence: "[knowledge management], a set of management activities aimed at designing and influencing knowledge creation and integration (including processes of sharing knowledge), has emerged as a particularly influential organizational competence that shapes the work environment" (p. 597).

One area of concern in the literature on knowledge management is tacit knowledge. While difficult to capture, such knowledge emerges in group settings through interaction with others experiencing the same work-based phenomena (Myers, 2018; Nonaka, 1994). Teams play an important role in capturing tacit knowledge and moving it to broader use in the organization (Crossan et al., 1999; Edmondson, 2002). Learning based on experience is intuited by individuals, then shared, interpreted, and integrated via grouplevel processes: "Collective learning is inherently local" (Edmondson, 2002, p. 142).

Closely related to knowledge management is the field of organizational learning which developed in the late 1970's from the disciplines of behavioral psychology and organizational behavior (Andrews, 2018). The main focus of this field is understanding how organizations change as they acquire experience; the discipline is concerned with knowledge creation, retention and transfer within an organization; it is also concerned with learning processes and outcomes (Argote, 2005; Raelin, 1997). Learning is the natural consequence of experience. People learn from experience, consciously and unconsciously; organizations, by definition composed of people, therefore also learn from experience. Much basic research in the fields of education and psychology has improved general understanding of the principles of learning. When members of an organization share insights from their experiences, they share tacit knowledge which may or may not become explicit over time (Andrews \& Smits, 2018; Nonaka, 1994; Yamklin \& Igel, 2012).

The learning organization, a concept which developed out of the organizational learning literature, focuses on assessing an organization's learning environment, and on conscious efforts which can be made by management to make the workplace more conducive to learning (Raelin, 1997). Context is important to 
learning, and managers influence the context of their organizations. Rowden (2001) traces the learning organization construct back to the work of Argyris and Schon (1996) and credits its conceptual foundation in systems theory to Senge (1990/2006). Rowden describes it as an organization which actively engages in identifying and solving problems, and experimenting to increase its capacity to learn; he describes four characteristics that distinguish the learning organization: "constant readiness, continuous learning, improvised implementation, and action learning" (p. 15). Garvin and associates (2008) specified the requirements for an organization to be considered a learning organization and developed an on-line survey to assess the degree to which an enterprise functions as one. The survey is conceived on the theory that in order for organizational learning to happen, three major factors are required referred to as "Building Blocks" : a supportive learning environment, concrete learning practices, and leadership that supports and reinforces learning. The survey's authors present benchmark scores as a reference for people taking the online survey to help them see how their responses compare to norms.

Clearly there is much overlap among the emerging disciplines of knowledge management and organizational learning as well as with the concept of the learning organization. The advances in these disciplines have been timely because there is a growing consensus regarding the importance of learning in today's dynamic business environment (Edmondson, 2008; Fisher \& Barrett, 2019; Hansen \& Birkinshaw, 2007; Reus, et al., 2009). Earlier in this article, links were drawn between learning and the different stages of organizational life cycles. We stressed that learning undergirds dynamic capabilities which are crucial to achieving organizational ambidexterity, and that exploration and exploitation both involve learning albeit of a different nature. The leveraging of learning and the management of knowledge is central to organizational development. As firms become more aware of the learning and knowledge embedded in tacit exchanges and routines, as they recognize it as a valuable resource, seek to cultivate new knowledge both internally and externally, and as firms implement concrete practices to disseminate it, they are doing so with greater levels of sophistication. This points to a tension between the need for firms in dynamic sectors to remain lean and innovative, on the one hand, versus efficient and systematic (hence more formalized) on the other. According to Nosella et al. (2012) the original definition of organizational ambidexterity referred to the capability to resolve such tensions.

\section{EXPLORATION AND EXPLOITATION IN E-COMMERCE FIRMS}

\section{Emergence of E-Commence}

Laudon and Traver (2017) define e-commerce as "digitally enabled commercial transactions between and among organizations and individuals." Such transactions take place on the Internet, using the World Wide Web, and Web browsers, and they include transactions made with mobile applications on mobile devices. Similar to traditional commerce, the two main types of e-commerce include business-to-consumer, and business-to-business. Even though business-to-consumer is the most often discussed and referred to form of e-commerce, business-to-business far outweighs the former in terms of value and volume of transactions (Andrews 2017, 2018 citing Brown, 2015; and Laudon \& Traver, 2017). Since the early 2000s, thanks to technological developments in mobile devices and on the Internet, new ways of buying and selling online have proliferated (Andrews, 2018). Media services companies like Spotify or Netflix allow consumers with subscriptions unlimited access to their digital audio and video repositories. Consumers can sell directly to other consumers thanks to online auctions such as eBay, and private individual car owners can rent their vehicles to nearby consumers thanks to services such as easyCar or Drivy. Furthermore, ride share companies such as Uber or Lyft exploit mobile platforms to match customers to drivers who use their personal vehicles to offer rides in a manner which competes with traditional taxi services (Petropolous, 2016). Platforms such as Airbnb, Uber and Drivy are often referred to as online marketplaces "because they process transactions for products and services provided by multiple third parties" (Andrews, 2018, p. 10, citing Laumeister, 2014; and Tozzi, 2008). Amazon is well known for running its own on-line marketplace.

E-commerce is much more than a new way to shop or a simple amelioration in business efficiency rendered possible by digital technology. Shapiro and Varian (1999) described the Internet as a "hybrid between a broadcast medium and a point-to-point medium" (p. 7). This aspect of the Internet, along with 
its universal standards give e-commerce many of its unique features including its ubiquity and global reach, its ability to facilitate interaction and customization, as well as the richness and density of the information exchanged (Laudon and Traver, 2017). To sum up, e-commerce has supplanted the dominance of manufacturing and inventory, changed how business is organized, and it has impacted every part of the global value chain; thus, over the past 20 years, many business models have had to contend with disruptive e-commerce technologies and practices (Andrews, 2018).

\section{A Recent Example for Discussion}

While organizations face increased developmental and survival challenges due to environmental complexity and uncertainty, and while knowledge workers have more responsibility for dealing with unforeseen change, advances in knowledge management and organizational learning have evolved in ways which can help them cope. Of particular importance has been the increased capacity of knowledge workers to learn from their shared experiences and for theoreticians and researchers to develop improved models and procedures to capture and apply these subtle forms of learning (Afshari \& Nasab, 2020; Ambrosini \& Bowman, 2001; Andrews, 2018; McIver, et al., 2013; and Myers, 2018).

A mixed-methods study by Andrews (2018) focused on assessing the firm-specific knowledge of a young, e-commerce organization and on capturing the tacit knowledge members acquired via their collective experiences implementing the founders' vision and strategic plan. This firm had been successful in gaining market share during its eight years of existence but had not yet become profitable. The first part of the methodology combined two approaches to capturing tacit knowledge: Causal Mapping (Ambrosini \& Bowman, 2001), and the knowledge-in-practice framework (McIver, et al, 2013). The goal of the semistructured interviews was first to elicit from participants constructs related to organizational success; second, to explore factors which undergirded these constructs; and, third, to investigate behaviors and tacit knowledge which enabled (caused) these factors to exist. By combining the causal mapping approach with the questions from the knowledge-in-practice framework, the causal map of success factors was extended to include the knowledge requirements for each factor. This interview technique encouraged knowledgesharing and often generated insights not only for the researcher(s) but also for the participants.

A second part of this mixed-method study included the use of the Learning Organization Survey (Garvin, et al., 2008). The survey results suggested the presence of a supportive learning environment in the company, and leadership that supported learning; however, the results also pointed a lack of concrete learning processes and practices. The overall findings of the mixed-methods study, including the results from the semi-structured interviews, suggested a firm experiencing tension between an entrepreneurial culture/history with a strong sense of collective mission, on the one hand, versus a need for greater efficiency and control, on the other. One possible conclusion is that the enterprise was cautiously moving towards a greater reliance on systems, in other words, towards the formalization stage according to Daft's 2010 organizational life cycle model. Another possible conclusion is that the firm was experiencing tension between the need for exploration versus exploitation, as per the concept of organizational ambidexterity discussed above. Findings and recommendations from the study were discussed with and validated by the company's management who intended to use it as the basis on which to design a training program to improve the retention, sharing and dissemination of knowledge among the company's employees.

\section{The Question of Formalization}

Discussion about the benefits versus the potential pitfalls of traditional formalization and linear management processes is certainly nothing new in the management literature. Takeuchi and Nonaka (1986) called for the management of new product development to move away from a traditional linear hierarchical approach towards one that was more flexible, holistic, reliant on self-managed teams, and client-focused. Such an approach became widely used in software development and achieved a movement-like status with the publication of the Agile Manifesto in 2001 (Beck et al., 2001; Gustavsson, 2016). Today companies such as Spotify have developed Agile management practices on a company-wide scale. Much more than a product development approach, Agile has become an all-encompassing management philosophy and is used in a wide range of industries and sectors (Conforto et al., 2014; Denning, 2018; Gustavsson, 2016; Putnik 
\& Putnik, 2012; Singh et al, 2013). The goal of implementing Agile practices, at Spotify, for example, is to achieve "minimal viable bureaucracy", which means "the least amount of structure and process we can get away with to avoid total chaos" (Kniberg, 2014b, 9:16). Much older and more established companies, such as the French insurance company AXA, one of the largest insurance groups in the world, appear to be heeding this call; AXA is attempting to implement Agile across multiple departments with the goal of organizing the whole company according to Agile management practices (Clapaud, 2018).

Although an initial reading of Takeuchi and Nonaka's 1986 piece on new product development might lead one to conclude that formalization is the enemy, and that this stance carries over into Agile practices, Agile management is actually rich with structures and formalization. Enormous companies such as AXA could never dispense with formalization, so clearly what is going on is a rethink of what formalization means and what formalization is good for. At Spotify, the Squad, which is described as a "small, crossfunctional, self-organizing team" of fewer than eight people (Kniberg, 2014a. 1:00) is the basic organizational unit designed to be as egalitarian as possible and to encourage tacit exchanges and informal learning. It is nevertheless a structure with defined roles, and one which overlaps and/or intersects with a number of other structures at Spotify including: Tribes, which are similar to matrixes; Chapters, which are competency areas; and Guilds, which are a type of company-supported community of practice (Kniberg, 2014a; Smite et al., 2020).

An assessment of the literature on Agile management practices, and the example of Spotify, suggest that structure and formalization in Agile are considered merely means to an end which can be abandoned quickly in favor of other structures, or simply less structure, if more effective. This stance is compatible with an organizational learning perspective. For example, Miller at al. (2006) conclude that organizations are not effective at codified, formal learning, and that most organizational learning is, on the contrary, tacit and informal. The function of an organization is to provide a social context where learning takes place. Developing and encouraging an innovative culture, and mindset would therefore appear to take precedence over the desirability for any specific formalized structures or processes, especially where knowledge management and organizational learning are concerned (Afshari \& Nasab, 2020).

When e-commerce firms implement systems to more effectively exploit the dynamic capabilities of the firm in order to make themselves efficient and profitable, such an evolution need not necessarily correspond to Daft's (2010) definition of formalization as characterized by "the formalization of rules and structure, conservatism and institutional procedures" (Andrews, 2018, p. 163, referring to Daft, 2010). Examples of concrete learning practices and processes to undergird and boost learning at Spotify include: holding meetings specifically to learn from failure; organizing competitions and games during which employees are encouraged to experiment on any project they wish to; improvement boards; boot camps for new hires; storytelling sessions; and "un-conferences" (Kniberg, 2014b). Moreover, while experiencing exponential growth, the company appears to be making effective use of an informal structure, "guilds", which are in fact communities of practice (Smite et al., 2020) to support the more formal structures. Agile management practices point to ways that leaders can guide a company through growth without necessarily stumbling into typical leadership crises (assumed to be inherent to the life cycle models of Greiner, 1972, Quinn and Cameron, 1983, and Daft, 2010), and without resorting to a rigid version of formalization, but by employing what we refer to as microstructures and practices which encourage and support informal learning and innovation rather than stifle it; this appears particularly relevant for e-commerce companies. As the question of buffering innovation is examined in the following two paragraphs, the concept of microstructures and practices is further explored.

\section{Buffering Innovation}

It is well established in the literature on entrepreneurship and product development that companies may best achieve innovative outcomes by isolating new projects, initiatives or ventures from the rest of the company. Discussing dimensions of intrapreneurship, Antoncic and Hisrich (2001), for example, state that "new business venturing is the most salient characteristic of intrapreneurship because it can result in a new business creation within an existing organization" (p. 498, citing Stopford and Baden-Fuller, 1994). In a large firm with substantial assets and personnel, this approach to buffer innovation can allow a small group 
of employees to work outside of the constraints which apply to the rest of the company's employees, constraints that make sense to maintain certain types of routines, and which might be necessary to ensure efficiency and predictability, but which stifle creativity. Moreover, this isolation may allow for a more innovative subculture to develop among the small group of employees which would otherwise probably not take hold. This approach implies a mature organization which is seeking renewed exploration through the elaboration of structures.

We suggest, however, that an Agile product development approach especially using the development iteration referred to as a sprint - an intense period of time lasting from two weeks to a month during which a small team works exclusively to achieve project goals and is usually isolated from the rest of the company (Beck et al., 2001; Conforto et al., 2014; Putnik \& Putnik, 2012) - can also be a way to buffer innovation, but one which is applicable to companies in early stages of development. In a younger company-like the recent example described in this paper - with limited resources, where roles are fluid and formalization limited, isolating a small team, particularly people with key knowledge and skills that are often highly demanded by the rest of the company (such as software developers), might serve to protect the team from the "chaos" of the rest of the company so they can temporarily devote all their time and energy to accomplishing an important task. With a smaller, less formalized enterprise, the goal of sprints, or similar practices, may be to buffer innovation through achieving a minimum level of formalization in an otherwise mostly informal and chaotic environment. Such formalization is on a micro-level and is likely to be temporary - hence it corresponds our concept of micro-formalization.

The e-commerce firm in the recent example described above was grappling with exploitation and exploration issues, as suggested previously. The company structure had been largely built around the concept of e-stores (one for each client brand), under the responsibility of brand managers. It's B2B fullservice activity was the mainstay of the company's turnover, and its core offer to clients, but was not generating a profit. This activity relied on processes and routines that had become largely standardized; the firm needed to render them efficient - i.e. successfully hone their exploitation of this activity. Meanwhile the company was also engaging in activities which can be considered exploration. For example, at the time of the study, the company had set up a new activity, Marketplace, alongside but largely separate from its B2B services and operations-hence representing an example of a structurally autonomous or semiautonomous unit referred to above (Antoncic \& Hisrich, 2001), but one implemented in a relatively young, entrepreneurial organization. The enterprise, despite not being a mature company by most definitions, thus shows characteristics of a firm striving to be ambidextrous as per March's definition (1991) - managing the tension between exploration and exploitation and doing so simultaneously (Guptat et al, 2006; Nosella et al., 2012; O’Reilly \& Tushman, 2013).

\section{CONCLUSION}

E-commerce has been transforming business activities across the global value chain for the past 20 years and the Covid-19 pandemic is clearly accelerating this transformation in nearly every sector of the economy including those which were not previously associated with e-commerce transactions such as insurance, banking, and medicine (Bowden et al., 2020). In such a context, young technology companies specialized in e-commerce activities must rapidly achieve superior performance and sustain it through continuous innovation. This paper has explored how the concept of organizational ambidexterity applies to e-commerce firms and how the dynamic capabilities required to achieve an optimal balance of exploration and exploitation are related to organizational learning and knowledge management, as well as to organizational development frameworks such as the organizational life cycle. A recent example of an ecommerce firm was summarized to ground the discussion in practice and to illustrate how research can help practitioners understand and leverage firm-specific knowledge in dynamic contexts. The final sub-sections of this paper focused on questions of formalization and on buffering innovation. The concept of microformalization was proposed which refers to the use of small organizational units or groups to accomplish specific tasks and projects of relatively short duration and which favor informal hierarchical arrangements; it also refers to the use of informal structures such as communities of practice to encourage the development 
of a social context where learning takes place. Agile management practices provide many examples of micro-formalization which we contend can help younger companies realize some of the advantages of Daft's (2010) formalization stage while avoiding the potential pitfalls of a full-blown formalization stage and the subsequent potential loss of innovation. We further propose that such management practices can help companies maintain learning loops, iterative cycles, and proximity to client needs required to survive in the long term as the firms mature. In turbulent and dynamic environments, companies will not necessarily evolve in ways that neatly correspond to traditional organizational life cycle models.

Many of the questions raised in this paper call for future research. For example, it would be beneficial to further explore how the concepts of organizational life cycles, knowledge management, and organizational ambidexterity are interrelated. Where and how they overlap, and the extent to which they describe similar phenomena and/or diverge could be clarified through additional empirical investigations, literature reviews, and meta-analyses. Another important question which future research should address is the extent to which organizational characteristics associated with the formalization and elaboration stages of Daft's 2010 organizational life cycle model are found in young technology companies (i.e. earlier in a company's history than the model would suggest) as these firms not only respond to their dynamic environments in innovative ways but actively shape them. This issue relates to the larger question of the applicability of existing models of organizational life cycles to the current turbulent business environment and/or to sectors such as e-commerce, and the extent to which alternative models should be developed. Moreover, there is a need for more empirical studies of Agile management practices-how they are applied, for what purpose and what their effect is in different companies, e.g. companies in the same sector but at different stages of development.

\section{REFERENCES}

Afshari, L., \& Nasab, A.H. (2020). Organizational culture, social capital, and knowledge management: An integrated model. International Journal of Knowledge Management, 16(2). https://doi.org/10.4018/IJKM.2020040104

Agrawal, A., \& Mukti, S K. (2020). Knowledge management \& its origin, success factors, planning, tools, applications, barriers, and enablers: A review. International Journal of Knowledge Management, 16(2). https://doi.org/10.4018/IJKM.2020010103

Ambrosini, V., \& Bowman, C. (2001). Tacit knowledge: Some suggestions for operationalization. Journal of Management Studies, 38(6), 811-829.

Andrews, M. (2017). Turbulent and dynamic times: The importance of tacit knowledge and organizational learning in a young e-commerce company. Journal of Organizational Psychology, 17(50), 37-51.

Andrews, M. (2018). Strategic value of tacit knowledge and learning processes in a young e-commerce company [Doctoral dissertation, International School of Business, Paris]. OpenDissertations.org Retrieved from https://library.biblioboard.com/viewer/70a57f48-90d6-47af-b6de-4e2f631f12d9

Andrews, M., \& Smits, S.J. (2018). Knowing what we know: Uncovering tacit knowledge for improved organizational performance. Journal of Organizational Psychology, 18(5), 26-43.

Antoncic, B., \& Hisrich, R. (2001). Intrapreneurship: Construct refinement and cross-cultural validation. Journal of Business Venturing, 16, 495-527.

Argote, L. (2005). Reflections on two views of managing learning and knowledge in organizations. Journal of Management Inquiry, 14(1), 43-48.

Argote, L., \& Miron-Spektor, E. (2009). Organizational learning: From experience to knowledge. New Perspectives in Organization Science. Pittsburgh, PA: Carnegie Mellon University.

Argyris, C., \& Schon, D.A. (1996). Organizational Learning II: Theory, Method, and Practice (Vol. 2). University of Michigan, Addison-Wesley Publishing Company.

Barrett, F.J. (1998). Creativity and improvisation in jazz and organizations: Implications for organizational learning. Organization Science, 9(5), 605-622.

Beck, K., Beedle, M., van Bennekum, A., Cockburn, A., Cunningham, W., Fowler, M., . . Thomas, D. (2001). Manifesto for Agile Software Development. Retrieved from www.agilemanifesto.org 
Bowden, D.E., Smits, S.J., \& Andrews, M. (2020, September 10). The challenge of knowledge management in healthcare [Paper presentation]. In $13^{\text {th }}$ Annual Conference of the EuroMed Academy of

Business. Palermo, Italy (Virtual conference).

Cawsey, T., \& Deszca, G. (2007). Toolkit for organizational change. Sage.

Clapaud, A. (2018, November 27). Comment Axa a imité avec succès le modèle Spotify pour aller vers l' « Agile at Scale ». LeMagIT. Retrieved from https://www.lemagit.fr/etude/Comment-Axa-a-imiteavec-succes-le-modele-Spotify-pour-aller-vers-l-Agile-at-Scale

Conforto, E.C., Salum, F., Amaral, D.C., da Silva S.L., \& Magnanini de Almeida, L.F. (2014, June-July). Can agile project management be adopted by industries other than software development? Project Management Journal, pp. 21-24.

Crossan, M.M., Lane, W.H., \& White, R.E. (1999). An organizational learning framework: From intuition to institution. Academy of Management Review, 24(3), 522-537.

Crossan, M.M., Maurer, C.C., \& White, R.E. (2011). Reflections on the 2009 AMR decade award: Do we have a theory of organizational learning? Academy of Management Review, 36(3), 446-460.

Daft, R.L. (2010). Organization theory and design (10th ed.). South-Western Cengage Learning.

Denning, S. (2018). The emergence of Agile people management. Strategy \& Leadership. https://doi.org/10.1108/SL-04-2018-0042

Edmondson, A.C. (2002). The local and variegated nature of learning in organizations: A group-level perspective. Organization Science, 13(2), 128-146.

Edmondson, A.C. (2008, July-August). The competitive imperative of learning. Harvard Business Review, pp. 60-67.

Eisenhardt, K.M., \& Martin, J.A. (2000). Dynamic capabilities: What are they? Strategic Management Journal, 21, 1105-1121.

Fisher, C.M., \& Barrett, F.J. (2019). The experience of improvising in organizations: A creative process perspective. Academy of Management Perspectives, 33(2), 148-162.

Fisher, G., Kotha, S., \& Lahiri, A. (2016). Changing with the times: An integrated view of identity, legitimacy, and new venture life cycles. Academy of Management Review, 41(3), 383-409.

Flamholtz, E.G., \& Randle, Y. (2007). Successful organizational development and growing pains. Management Online Review. ESCP-EAP European School of Management.

Garvin, D.A., Edmondson, A.C., \& Gino F. (2008, March). Is yours a learning organization? Harvard Business Review. Retrieved from https://hbr.org/2008/03/is-yours-a-learning-organization.

Greiner, L.E. (1972, July-August). Evolution and revolution as organizations grow. Harvard Business Review, pp. 37-36. Retrieved from https://hbr.org/1998/05/evolution-and-revolution-asorganizations-grow

Gupta, A.K., Smith, K.G., \& Shalley, C.E. (2006). The interplay between exploration and exploitation. Academy of Management Journal, 49(4), 693-708.

Gustavsson, T. (2016, April 14-16). Benefits of agile project management in a non-software development context - A literature review [Paper presentation]. Fifth International Scientific Conference on Project Management in the Baltic Countries, Riga, University of Latvia.

Hansen, M.T., \& Birkinshaw, J. (2007, June). The innovation chain. Harvard Business Review, pp. 121130.

Jirasek, M., \& Bilek, J. (2018). The organizational life cycle: Review and future agenda. Quality Innovation Prosperity, 23(1), 1-18. http://dx.doi.org/10.12776/qip.v22i3.1177

Junni, P., Sarala, R.M., Taras, V., \& Tarba, S.Y. (2013). Organizational ambidexterity and performance: A meta-analysis. Academy of Management Perspectives, 27(4), 299-312.

Kniberg, H. (2014). Spotify engineering culture - Part 2 [Video]. Retrieved from https://www.youtube.com/watch?v=vOt4BbWLWQw

Kniberg, H. (2014). Spotify engineering culture [Video]. Retrieved from https://www.youtube.com/watch?v=4GK1NDTWbkY\&t=621

Laudon, K.C., \& Traver, C.G. (2017). E-commerce 2016: Business, technology, society (12th ed.). Pearson Education Limited. 
Laumeister, G. (2014, August 20). Why online marketplaces are booming. Retrieved from http://www.forbes.com/sites/groupthink/2014/08/20/why-online-marketplaces-arebooming/print/

Lawrence, T.B., Mauws, M.K., Dyck, B., \& Kleysen, R.F. (2005). The politics of organizational learning: Integrating power into the 4I framework. Academy of Management Review, 30(1), 180-191.

March, J.G. (1991). Exploration and exploitation in organizational learning. Organization Science, 2(1), 71-87.

March, J.G. (1996). Continuity and change in theories of organizational action. Administrative Science Quarterly, 41, 278-287.

March, J.G. (2006). Rationality, foolishness, and adaptive intelligence. Strategic Management Journal, 27, 201-214

McIver, D., Lengnick-Hall, C.A., Lengnick-Hall, M.L., \& Ramachandran, I. (2013). Understanding work and knowledge management from a knowledge-in-practice perspective. Academy of Management Review, 38(4), 597-620.

Miller, K.D., Zhao, M., \& Calantone, R.J. (2006). Adding interpersonal learning and tacit knowledge to March's exploration-exploitation model. Academy of Management Journal, 49(4), 324-338.

Myers, C.G. (2018). Coactive vicarious learning: Toward a relational theory of vicarious learning in organizations. Academy of Management Review, 43(4), 610-634.

Nonaka, I. (1994). A dynamic theory of organizational knowledge creation. Organization Science, 5(1), 14-37.

Nosella, A., Cantarello, S., \& Filipinni R. (2012). The intellectual structure of organizational ambidexterity: A bibliographic investigation into the state of the art. Strategic Organization, 10(4), 450-465.

O'Reilly, C.A., III, \& Tushman, M.L. (2013). Organizational ambidexterity: Past, present, and future. Academy of Management Perspectives, 27(4), 324-338.

O'Reilly, C.A., III., \& Tushman, M.L. (2004, April). The ambidextrous organization. Harvard Business Review, pp. 74-81.

Petropolous, G. (2016, February 22). Uber and the economic impact of sharing economy platforms [Blog post]. Retrieved from http://bruegel.org/2016/02/uber-and-the-economicimpact-of-sharingeconomy-platforms/

Porter, M.E. (2008, January). The five competitive forces that shape strategy. Harvard Business Review, pp. 79-93.

Prusak, L. (2001). Where did knowledge management come from? IBM Systems Journal, 40(4), 1002.

Putnik, G.D., \& Putnik, Z. (2012). Lean vs agile in the context of complexity management in organizations. The Learning Organization, 19(3), 248-266.

Quinn, R.E., \& Cameron, K. (1983). Organizational life cycles and shifting criteria of effectiveness: Some preliminary evidence. Management Science, 29(1), 33-51.

Raelin, J.A. (1997). A model of work-based learning. Organization Science, 8(6), 563-578.

Reus, T.H., Ranft, A.L., Lamont, B.T., \& Adams, G.L. (2009). An interpretive systems view of knowledge investments. Academy of Management Review, 34(3), 382-400.

Rowden. R.W. (2001). The learning organization and strategic change. Advanced Management Journal, 66(3), 11-16.

Senge, P. (2006). The fifth discipline: The art and practice of the learning organization. Doubleday. (Original work published in 1990).

Shapiro, C., \& Varian, H.R. (1999). Information rules: A strategic guide to the network economy. Harvard Business School Press.

Singh, J., Sharma, G., Hill, J., \& Schnackenberg, A. (2013, January). Organizational agility: What it is, what it is not, and why it matters. In Academy of Management Proceedings, 2013(1). Retrieved from https://journals.aom.org/doi/10.5465/ambpp.2013.11813abstract

Smite, D., Moe, N.B., Floryan, M., Levinta, G., \& Chatzipetrou, P. (2020, March). Spotify guilds. Communications of the ACM, 63(3), 56-61. https//doi:10.1145/3343146

Smits, S.J., \& Bowden, D.E. (2015). A perspective on leading and managing organizational change. Economics and Business Review, 15(2), 3-21. 
Spender, J. (1993). Competitive advantage from tacit knowledge? Unpacking the concept and its strategic implications. Academy of Management Best Papers Proceedings, pp. 37-41.

Stopford, J.M., \& Baden-Fuller, C.W.F., (1994). Creating corporate entrepreneurship. Strategic Management Journal, 15(7), 521-536.

Takeuchi, H., \& Nonaka, I. (1986, January-February). The new product development game. Harvard Business Review, pp. 137-146.

Teece, D.J. (2014). A dynamic capabilities-based entrepreneurial theory of the multinational enterprise. Journal of International Business Studies, 45(1), 8-37.

Teece, D.J., (2007). Explicating dynamic capabilities: the nature and microfoundations of (sustainable) enterprise performance. Strategic Management Journal, 28(13), 1319-1350.

Teece, D.J., Pisano, G., \& Shuen, A. (1997). Dynamic capabilities and strategic management. Strategic Management Journal, 18(7), 509-533.

Tozzi, J. (2008, July 11). Determining where to sell online. Retrieved from https://www.bloomberg.com/news/articles/2008-11-07/determining-where-tosellonlinebusinessweek-business-news-stock-market-and-financial-advice

Turner, K.L., \& Makhija, M.V. (2006). The role of organizational controls in managing knowledge. Academy of Management Review, 31(1), 197-217.

Tushman, M., \& Nadler, D. (1986). Organizing for innovation. California Management Review, 28(3), 74-92.

Yamklin, S., \& Igel, B. (2012). Communities of practice purposely designed for improving business performance. Knowledge and Process Management, 19(4), 189-202. 